\title{
Are Crops Still Profitable in Cauvery River Basin of Karnataka?
}

\author{
Ashwini B.C. ${ }^{1 *}$ and V.R. Kiresur ${ }^{2}$ \\ ${ }^{1}$ Department of Agricultural Economics, University of Agricultural Sciences, Dharwad-580005, Karnataka, India \\ ${ }^{2}$ Department of Agricultural Economics, UASD College of Agriculture, Vijayapur-586101, Karnataka, India \\ *Corresponding author: ashwinismile813@gmail.com
}

\begin{abstract}
The study attempts to estimate the profitability of crops cultivated in Cauvery river basin of Karnataka. The study uses primary data pertaining to Mandya district, which is the major beneficiary of the Krishna Raja Sagara (KRS) Project of Cauvery basin for irrigation purpose. For this study, 120 farm households were selected through appropriate sampling procedure. The data thus collected were processed using statistical tools including descriptive analytical tools, Cobb-Douglas Production Function and Garrett ranking method. The results revealed that, in the study area, sugarcane was the most profitable crop with a mean net returns of $₹ 1,47,288$ per ha and a benefit-cost ratio of 2.02 . The corresponding figures for paddy were ₹ 31,342 per ha and 1.52, while for ragi, they were ₹ 3,159 per ha and 1.12. Over the last decade, maize, banana, sesamum and coconut have gained importance as indicated by their significant positive high compound annual growth rates in cropped area, which is a desirable change replacing the age-old monotonous sugarcane-paddy cropping system. Labour scarcity and high wage rate were the serious problems faced by the sample respondents in crop production. Amongst the irrigation related problems, untimely and inadequate release of water from the dam for irrigation purposes and sedimentation in canals and tanks were the most serious ones, which needs the attention of the policy makers on priority basis, in order to have a sustainable crop production system in the region.
\end{abstract}

Keywords: Cropping system, Profitability, Cobb-Douglas, Garrett ranking and Problems faced by the farmers.

India is a monsoon dependent country for its water resources. Irrigation sector has been fundamental to India's economic development and poverty alleviation since 25 per cent of India's Gross Domestic Product (GDP) and 65 per cent of employment is based on agriculture. During the post independence period, the country has invested a huge amount of capital in the major and the medium irrigation projects. In Cauvery basin of Karnataka major irrigation projects are Kabini, Harangi, Hemavathi and Krishnaraja Sagara. These irrigation infrastructures in Cauvery basin of Karnataka have helped provide sufficient quantity of irrigation water to the cultivation of crops in the region.

Irrigation first increased the options available to the residents of villages with irrigation. But as the benefits of irrigation grew more slowly and even began to decline in drought years, the increased economic and political power of the newly irrigated regions in Karnataka made them much more aggressive in their demand for a greater share of the Cauvery water. Mandya district which was the major beneficiary of the Krishnarajasagar dam became the centre for mass mobilisation over the Cauvery dispute (Narendra, 2009).

The Cauvery river water sharing has been disputed politically and socially since long time. The water sharing mechanism has been facing several problems, the first and the foremost being the water scarcity (water stress). That is, the water used for agriculture, industrial and drinking purposes is more than the amount of renewable water available. Therefore, the river water is heavily used and much 
more needed. The irrigation of almost 1.2 million ha of agricultural land (Bohle, 2004) in Karnataka and Tamil Nadu requires over 90 per cent of the Cauvery's water, mainly for the cultivation of water intensive crops like paddy and sugarcane (Prasad, 2007).

The present study is an attempt to assess the profitability of major crops cultivated in the study area, and to identify and assess the problems faced by farmers in the study area.

\section{Methodology}

Stratified random sampling technique was followed to select the sample respondents. Mandya district, which falls in the Cauvery basin, was purposively selected for the study, since the district is the major beneficiary of the Krishna Raja Sagara (KRS) Project of Cauvery basin for irrigation purposes. From Mandya district, two talukas, namely, Srirangapatna and Malavalli were selected, based on proportion of irrigated area so as to represent the district. From each taluka, two villages were selected. From each village, 30 farmers were selected using proportionate random sampling technique. Thus, in all, the sample of respondents consisted of 120 farmers drawn from 4 villages spread across 2 talukas in Mandya district.

\section{Cobb-Douglas Production Function}

Multiple regression technique was used to examine the influence of different factors, namely, farm size, seeds, fertilizers, human labour, bullock labour, machine labour and irrigation charge on output of paddy, sugarcane and ragi.

Cobb-Douglas type of production function, of the following form, was fitted to the data.

$$
\mathrm{Y}=\mathrm{a} \cdot \mathrm{X}_{1}^{\mathrm{b} 1} \cdot \mathrm{X}_{2}^{\mathrm{b} 2} \cdot \mathrm{X}_{3}^{\mathrm{b} 3} \cdot \mathrm{X}_{4}^{\mathrm{b} 4} \cdot \mathrm{X}_{5}^{\mathrm{b} 5} \cdot \mathrm{X}_{6}^{\mathrm{b} 6} \cdot \mathrm{X}_{7}^{\mathrm{b} 7} \cdot \mathrm{e}^{\mathrm{u}}
$$

In logarithmic form, it assumed a log-linear equation as under:

$\log Y=\log a+b_{1} \log X_{1}+b_{2} \log X_{2}+b_{3} \log X_{3}+$ $b_{4} \log X_{4}+b_{5} \log X_{5}+b_{6} \log X_{6}+b_{7} \log X_{7}+u$ $\log \mathrm{e}$.

Where,

$$
\begin{aligned}
& Y=\text { Gross returns }(₹ / \text { farm }) \\
& X_{1}=\text { Farm size }(\mathrm{Ha}) \\
& X_{2}=\text { Seeds }(₹ / \text { farm })
\end{aligned}
$$

$\mathrm{X}_{3}=$ Fertilizers $(₹ /$ farm $)$

$\mathrm{X}_{4}=$ Human labour $(₹ /$ farm $)$

$X_{5}=$ Bullock labour (₹/farm)

$\mathrm{X}_{6}=$ Machine labour (₹/farm)

$\mathrm{X}_{7}=$ Irrigation charge $(₹ /$ farm $)$

$\mathrm{a}=$ Constant/intercept term

$\mathrm{u}=$ Random variable

$\mathrm{e}=2.718$

$b_{1}$ to $b_{7}=$ Production elasticities / Regression Coefficients.

\section{Garrett Ranking}

The problems faced by farmers in the study area were prioritized by using Garrett ranking technique. For this, nine production related problems and four irrigation related problems were identified and all the 120 respondents were asked to rank the most important problems faced by them in the order of their seriousness. Then, the rank assigned to each problem by each individual was converted into per cent position using the following formula:

$$
\text { Per cent position }=100\left(\mathrm{R}_{\mathrm{ij}}-0.5\right) / \mathrm{N}_{\mathrm{j}}
$$

where,

$R_{i j}=$ Rank given for the $i^{\text {th }}$ factor $(i=1,2, \ldots, 9$ for production related constraints, $1,2, \ldots 4$ for irrigation and market related problems) by the $j^{\text {th }}$ individual $(j=1,2 \ldots \ldots .120)$, and

$N_{j}=$ Number of factors ranked by the $j^{\text {th }}$ individual.

In the next stage, scores were determined for each per cent position by referring to Garrett's table. Then, the scores for each problem were summed over the number of respondents who ranked that factor and mean scores were calculated by dividing the total score with the number of respondents who gave ranks. Final overall ranking of the nine (production related) and four (irrigation related) factors was done by assigning rank $1,2,3 \ldots$, etc. in the descending order of the mean scores.

\section{RESULTS AND DISCUSSION}

\section{Socio-economic characteristics of sample farmers}

The socio-economic characteristics of sample farmers presented in Table 1 revealed that majority 
of the respondents were belonging to middle age group. The average age of the sample farmers was 45.43 years. From this it could be inferred that, farmers of middle age were enthusiastic and had more work efficiency than the older and younger ones. Further, individuals of 35 to 50 years of age group had more physical vigour and had more family responsibility than the younger ones. These might be the important reasons to find majority of the respondents in the age group of 35 to 50 years (Ningareddy, 2005). Pradeep (2006) has also revealed that, majority of the sample farmers did lie in the middle age group because of non-availability of job facilities in the study area for throughout the year.

Table 1: Socio-Economic Characteristics of sample farmers $(n=120)$

\begin{tabular}{|c|c|c|c|c|}
\hline $\begin{array}{l}\text { S1. } \\
\text { No. }\end{array}$ & Particulars & Unit & Average & $\begin{array}{l}\% \text { to } \\
\text { total }\end{array}$ \\
\hline 1 & Age of the farmer & Years & 45.43 & \\
\hline \multirow[t]{3}{*}{2} & Gender & Number & & \\
\hline & Male & & 114 & 95.00 \\
\hline & Female & & 6 & 5.00 \\
\hline \multirow[t]{6}{*}{3} & Education & Number & & \\
\hline & Illiterate & & 12 & 10.00 \\
\hline & Primary/Secondary & & 30 & 25.00 \\
\hline & High school & & 62 & 51.67 \\
\hline & College & & 11 & 9.17 \\
\hline & Higher education & & 5 & 4.17 \\
\hline \multirow[t]{3}{*}{4} & Family type & Number & & \\
\hline & Joint & & 35 & 29.17 \\
\hline & Nucleus & & 85 & 70.83 \\
\hline \multirow[t]{4}{*}{5} & Occupation & Number & & \\
\hline & Agriculture & & 83 & 69.17 \\
\hline & $\begin{array}{l}\text { Agriculture + Other } \\
\text { business }\end{array}$ & & 32 & 26.66 \\
\hline & $\begin{array}{l}\text { Other job + } \\
\text { Agriculture }\end{array}$ & & 5 & 4.17 \\
\hline \multirow[t]{4}{*}{6} & Annual income & Rs & & \\
\hline & Main & & 70,152 & 82.19 \\
\hline & Subsidiary & & 15200 & 17.80 \\
\hline & Total & & 85352 & \\
\hline \multirow[t]{5}{*}{7} & Family composition & Number & & \\
\hline & Male & & 2.32 & 39.45 \\
\hline & Female & & 2.28 & 38.77 \\
\hline & Children & & 1.28 & 21.76 \\
\hline & Total & & 5.88 & \\
\hline
\end{tabular}

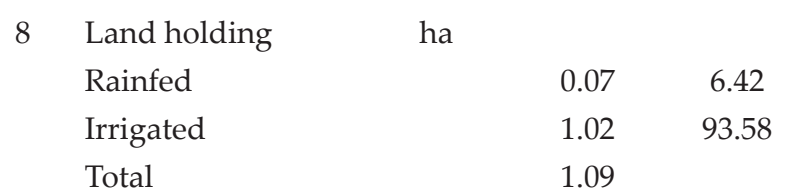

About 52 per cent of the respondents were educated up to high school, followed by 25 per cent upto primary and secondary school. Nearly 10 per cent were illiterate, 9.17 per cent were admitted to college and only 4.17 per cent got educated upto degree and above. In general, the respondents were educated. This could be a result of a common social environment. In the present scenario, almost everybody wants to be literate because of the awareness about the importance of the education by the various government programmes (Ningareddy, 2005). The result was in line with the findings reported by Pradeep (2006), who revealed that the average education level of sample farmers was upto high school. Due to non-availability of educational institutions for higher studies locally, people were forced to leave the native place for the sake of higher education.

Majority $(71 \%)$ of the sample farmers belonged to the nuclear family type while, remaining belonged to joint family type in the study area. This might be due to the changing values of family system.

Under the occupational pattern, around 69 per cent of the population was dependent only on agriculture because the availability of surface water was good due to which returns obtained from the water-intensive crops like paddy and sugarcane was profitable. On the other hand, about 27 per cent of the population was dependent on agriculture coupled with other business. Along with the agriculture some of the respondents were involved in subsidiary activities like grocery stores, mills, other petty business and works outside the field because of their small holding. The result was in line with the findings of Pavankumar (2011). About 82 per cent of the annual income of the farm households came from the main occupation and remaining 18 per cent from the subsidiary occupation. The average male population was slightly higher (2.32) than female population (2.28), while that of children 1.28, the overall average family size being 5.88 members. This was slightly higher than the ideal size of the family as proposed by Puhazendi (2000) in a study wherein the average 
size of the family was 3.85 , which closely confirmed to norms specified as ideal size of the family.

Most (93.58\%) of the land holding was irrigated, while the remaining was rainfed area $(6.42 \%)$. This was due to the fact that in the study area water for irrigation was sufficiently available from KRS reservoir (Cauvery river) and existence of wellbuilt canal system. The results were found to be in conformity with the study conducted by Pradeep (2006).

\section{Output and Labour Utilisation Pattern in Major Crops in Mandya District}

Output and labour uutilization ppattern in mmajor crops in the selected taluks presented in the Table 2 revealed that Srirangapatna scored over Malavalli in terms of yields of main products of all the crops under study, namely, paddy, sugarcane and ragi. In other words, the output obtained from paddy was the higher in Srirangapatna taluk (75.15 q) than in Malavalli taluk (62.37 q). The corresponding figures were $1202.50 \mathrm{q}$ and $1137.50 \mathrm{q}$ for sugarcane and 25 $\mathrm{q}$ and $24.47 \mathrm{q}$ for ragi. Amongst crops, the yields of main product were the highest for sugarcane, followed by paddy and ragi. The differences in byproduct yields in the case of paddy and ragi were not significant.

The usage of human labour, bullock labour and machine labour for three selected crops was also estimated and analysed. The usage of human labour in sugarcane crop was higher in Malavalli taluka (219.10 man-days) than in Srirangapatna taluka (217.30 man-days). Similarly, in the case of paddy, Srirangapatna (64.52 man-days) scored over Malavalli taluk (61.57 man-days) However, it was reverse in the case of ragi (43.756 man days in
Srirangapatna taluk and 45.70 man days in Malavalli taluk).

The utilization of bullock and machine labour was the highest in sugarcane crop, followed by paddy and ragi. Between taluks, again it was Srirangapatna that scored over Malavalli in all the three selected crops, with the lone exception of bullock labour usage in sugarcane.

Among the selected crops, the highest yield was obtained in sugarcane crop in Srirangapatna because of availability of sufficient quantity of canal water over the years and the soil type which also influenced the yield level. As compared to Malavalli taluk availability of both canal water and soil type was better in Srirangapatna taluk as indicated by higher productivity of all the crops in the region compared to Malavalli. In case of human labour, more labour (both male and female) utilization was observed in sugarcane crop compared to paddy and ragi, mainly because of difference in crop duration. This was true with bullock and machine labour usage.

\section{Details of Irrigation to Major Crops in the Study Area}

The details of irrigation for the selected crops presented in the Table 3 showed that the main source of irrigation in both the taluks was canal irrigation (through K.R.S. dam). Through Virija and Right Bank Low Level (RBLL) nalas water was available for crop cultivation in Srirangapatna taluk, whereas in Malavalli taluk, Vishweshwaraiah and RBLL nalas were the two important channels for water source. Method of irrigation adopted was flood irrigation for almost all the crops which were grown in the district. The availability of canal water

Table 2: Output and Labour Utilisation Pattern in Major Crops in Mandya District (per ha)

\begin{tabular}{|c|c|c|c|c|c|c|c|}
\hline \multirow{2}{*}{ S1. No. } & \multirow{2}{*}{ Particulars } & \multicolumn{2}{|c|}{ Paddy } & \multicolumn{2}{|c|}{ Sugarcane } & \multicolumn{2}{|c|}{ Ragi } \\
\hline & & Srirangapatna & Malavalli & Srirangapatna & Malavalli & Srirangapatna & Malavalli \\
\hline 1 & Main product output (q) & 75.15 & 62.37 & 1202.50 & 1137.50 & 25 & 24.47 \\
\hline 3 & Male labour (man-days) & 33.22 & 26.80 & 124.27 & 114 & 21.85 & 25.35 \\
\hline 4 & Female labour (man-days) & 31.30 & 34.77 & 93.02 & 105.1 & 21.9 & 20.35 \\
\hline 6 & Bullock labour (pair-days) & 7.5 & 6.25 & 17.15 & 17.5 & 3.82 & 2.50 \\
\hline 7 & Machine labour (hours) & 6.25 & 5.00 & 10.72 & 8.15 & 2.50 & 2.50 \\
\hline
\end{tabular}


Table 3: Details of Irrigation in Crop Production in Mandya District

\begin{tabular}{|c|c|c|c|c|c|c|c|}
\hline \multirow{2}{*}{$\begin{array}{l}\text { Sl. } \\
\text { No. }\end{array}$} & \multirow[t]{2}{*}{ Particulars } & \multicolumn{2}{|c|}{ Paddy } & \multicolumn{2}{|c|}{ Sugarcane } & \multicolumn{2}{|c|}{ Ragi } \\
\hline & & Srirangapatna & Malavalli & Srirangapatna & Malavalli & Srirangapatna & Malavalli \\
\hline 1 & $\begin{array}{c}\text { Area } \\
\text { irrigated (ha/ } \\
\text { household) }\end{array}$ & 1.01 & 0.65 & 1.17 & 0.81 & 0.63 & 0.77 \\
\hline 2 & $\begin{array}{l}\text { Source of } \\
\text { irrigation }\end{array}$ & $\begin{array}{l}\text { Virija nale and } \\
\text { RBLL canal }\end{array}$ & $\begin{array}{c}\text { Visveswaraiah } \\
\text { Canal and RBLL } \\
\text { canal }\end{array}$ & $\begin{array}{l}\text { Virija nale and } \\
\text { RBLL canal }\end{array}$ & $\begin{array}{c}\text { Visveswaraiah } \\
\text { Canal and RBLL } \\
\text { canal }\end{array}$ & $\begin{array}{l}\text { Virija nale and } \\
\text { RBLL canal }\end{array}$ & $\begin{array}{c}\text { Visveswaraiah } \\
\text { Canal and RBLL } \\
\text { canal }\end{array}$ \\
\hline 3 & $\begin{array}{l}\text { Method of } \\
\text { irrigation }\end{array}$ & Flood & Flood & Flood & Flood & Flood & Flood \\
\hline 4 & $\begin{array}{l}\text { Availability of } \\
\text { water during } \\
\text { summer }\end{array}$ & Once in 10 days & Once in a month & Once in 10 days & Once in a month & Once in 10 days & $\begin{array}{l}\text { Once in a } \\
\text { month }\end{array}$ \\
\hline 5 & $\begin{array}{l}\text { Adequacy of } \\
\text { water }\end{array}$ & Good & Below average & Good & Below average & Good & Below average \\
\hline 6 & $\begin{array}{l}\text { Price paid } \\
\text { for irrigation } \\
\text { water (₹/ha) }\end{array}$ & 500 & 500 & 1000 & 1000 & 87.50 & 87.50 \\
\hline
\end{tabular}

was continuous in kharif season and in summer it was available once in 10 days in Srirangapatna taluk and once in a month in Malavalli taluk as it was a tail-end region, resulting in scarcity of water to the crop grown in the region. Therefore the adequacy of water was good in Srirangapatna taluk, while it was poor in Malvalli taluk. Price paid for irrigation water was ₹ 1000 per ha for sugarcane, ₹ 500 for paddy and ₹ 87.50 for ragi crop. Pricing of irrigation water was done on flat rate or crop rate basis, that is, on cost per hectare criterion. The average area irrigated was the highest in sugarcane crop (1.17 ha in Srirangapatna and 0.81 ha in Malavalli), followed by paddy (1.01 ha in Srirangapatna and 0.65 ha in Malavalli) and ragi (0.63 ha in Srirangapatna and 0.77 ha in Malavalli). In general, Srirangapatna taluk had higher irrigated area for sugarcane and paddy compared to Malavalli taluk, whereas in ragi, it was the other way round.

\section{Cost and Returns of Paddy Cultivation in Srirangapatna and Malavalli Taluks of Mandya district}

Cost-returns profile of paddy in Srirangapatna and Malavalli taluks of Mandya district is presented in the Table 4. The results showed that the total cost (TC) of paddy in the study area was ₹ 59,877 per ha, out of which ₹ 36,172 (about 60 per cent) was the total variable cost (TVC) and the remaining ₹ 23,718 (39.64 per cent) was the total fixed cost
(TFC). Amongst the selected taluks, the total cost of paddy was highest in the case of Srirangapatna (₹ 61,771/ha) out of which TVC contributes 61.29 per cent and TFC contributes 38.70 per cent and in Malavalli taluk the TC of paddy was ₹ 58,411 per ha out of which TVC contributes 58.36 per cent and TFC contributes 40.35 per cent. The cost of paddy cultivation was found to be relatively higher in Srirangapatna taluk due to higher variable and fixed costs (Table 4). Higher variable cost was due to higher wage rate on account of non-availability of labour.

Table 4: Cost and Returns of Paddy in Srirangapatna and Malavalli taluks of Mandya District (2012-13) (₹ per ha)

\begin{tabular}{lcccc}
\hline $\begin{array}{l}\text { S1. } \\
\text { No. }\end{array}$ & & & \\
\hline I & Costiculars Srirangapatna & Malavalli & Mandya \\
& TVC & $37,865(61.29)$ & $34,089(58.36)$ & $36,172(60.41)$ \\
& TFC & $23,906(38.70)$ & $23,573(40.35)$ & $23,718(39.61)$ \\
& TC & $61771(100)$ & $58,411(100)$ & $59877(100)$ \\
II & Returns & & & \\
& TR & 96,306 & 84,648 & 91,219 \\
& NR & 34,536 & 26,237 & 31,342 \\
& B:C Ratio & 1.55 & 1.45 & 1.52 \\
\hline
\end{tabular}

Note: TVC, TFC, TC, TR, NR and BC ratio denote Total Variable Cost, Total Fixed Cost, Total Cost, Total Returns, Net Returns and Benefit Cost ratio, respectively.

Figures in the parentheses indicate percentage to the total cost. 
Gross returns of paddy in Mandya district was ₹ 91,219 per ha and the net returns was ₹ 31,342 per ha, the benefit-cost $(\mathrm{BC})$ ratio being 1.52. The gross returns were comparatively higher in Srirangapatna taluk ( $₹ 96,306$ ) than in Malavalli ( $₹ 84,648$ ). Similarly, the net returns and BC ratio were the higher in the case of Srirangapatna taluk (₹ 34,536; 1.55), than in Malavalli (₹ 26,237; 1.45). Higher magnitude of gross returns from paddy could be attributable to the increase in the prices of both main product and by-product of paddy over the years and increase in yield due to sufficient supply of canal water in all the seasons. On the other hand, the total cost, gross returns and net returns were comparatively low in the case of Malavalli taluk, due to untimely and insufficient water supply during summer season, given the fact that Malavalli is a tail end region. The result was in line with the findings of Harish (2006).

\section{Cost and Returns of Sugarcane Cultivation in Srirangapatna and Malavalli Taluks of Mandya District}

The costs-returns profiles of sugarcane in Srirangapatna and Malavalli taluks of Mandya district are presented in the Table 5. The results showed that the total cost of sugarcane in the study district as a whole was ₹ 1,44,599 per ha, out of which about 63 per cent was the TVC and the remaining 37 per cent was the TFC. In the selected taluks, the TC per ha for sugarcane was higher in the case of Srirangapatna ( $₹ 1,45,410$ ), than in Malavalli (₹ 1,43,875). In the case of Srirangapatna, the contributions of TVC and TFC were 62.73 per cent and 37.27 per cent, respectively. Similarly, in case of Malavalli, the contributions of the TVC and TFC to the TC were to the tune of 61.81 per cent and 38.11 per cent, respectively.

Gross return of sugarcane in Mandya district was ₹ $2,91,887$ per ha and the net return was ₹ $1,47,288$ per ha, the $\mathrm{BC}$ ratio being was 2.02 . The higher gross return per ha was found in the case of Srirangapatna taluk (₹ $3,06,875$ ), compared to Malavalli (₹ 2,78,505). The net return per ha and BC ratio were the higher in the case of Srirangapatna (₹ $1,61,465 ; 2.11$ ), than in Malavalli (₹ $1,34,630 ; 1.94$ ). Gross and net returns were low as the productivity of sugarcane in the region was very low. The locally cultivated variety CO-86032 was highly prone to woolly aphid infestation. In addition, scarcity of water in summer has had affected the yield of the crop adversely.

Table 5: Cost and Returns of Sugarcane in Srirangapatna and Malavalli taluks of Mandya District (2012-13) (₹ per ha)

\begin{tabular}{ccccc}
\hline $\begin{array}{c}\text { Sl. } \\
\text { No. }\end{array}$ & Particulars & Srirangapatna & Malavalli & Mandya \\
\hline I & Costs & & & \\
& TVC & 91,210 & 89,054 & 91,392 \\
& & $(62.73)$ & $(61.89)$ & $(63.20)$ \\
& TFC & 54,200 & 54,821 & 53,208 \\
& & $(37.27)$ & $(38.11)$ & $(36.79)$ \\
& TC & $1,45,410$ & $1,43,875$ & $1,44,599$ \\
& & $(100)$ & $(100)$ & $(100)$ \\
II & Returns & & & \\
& TR & $3,06,875$ & $2,78,505$ & $2,91,887$ \\
& NR & $1,61,465$ & $1,34,630$ & $1,47,288$ \\
& B:C Ratio & 2.11 & 1.94 & 2.02 \\
\hline
\end{tabular}

Note: TVC, TFC, TC, TR, NR and BC ratio denote Total Variable Cost, Total Fixed Cost, Total Cost, Total Returns, Net Returns and Benefit Cost ratio, respectively.

Figures in the parentheses indicate percentage to the total cost.

\section{Cost and Returns of Ragi in Srirangapatna and Malavalli Taluks of Mandya District}

The costs-returns profile of ragi in Srirangapatna and Malavalli taluks of Mandya district is presented in the Table 6 . The results showed that the total cost of ragi in the study area was ₹ 25,365 per ha out of which ₹ 20,412 (80.47 per cent) was the TVC and the remaining ₹ 4,953 (19.52 per cent) was the TFC. Amongst the selected taluks, the TC of ragi cultivation was higher in the case of Srirangapatna (₹ 25,544), than in Malavalli (₹ 25,257). In the case of Srirangapatna, the TVC contributed 80.23 per cent (₹ 20,658 per ha) and the TFC contributed 19.13 per cent (Rs.4,887 per ha) to the TC. Similarly, in the case of Malavalli, the contributions of TVC and TFC were to the tune of 80.23 per cent and 19.77 per cent.

Gross return from ragi in Mandya district was to the tune of ₹ 28,524 per ha and the net return was ₹ 3,159 per ha, the $\mathrm{BC}$ ratio being 1.12 . It was interesting to note that the higher gross return was in Malavalli taluka (₹ 28,667), than in Srirangapatna (₹ 28,381). The net return per ha and the $\mathrm{BC}$ ratio were the higher in the case of Malavalli (₹ 3,409; $1.13)$, than in Srirangapatna (₹ 2,837; 1.11). 
Table 6: Cost and returns of ragi in Srirangapatna and Malavalli taluks of Mandya district (2012-13) (₹ per ha)

\begin{tabular}{ccccc}
\hline $\begin{array}{c}\text { Sl. } \\
\text { No. }\end{array}$ & Particulars & Srirangapatna & Malavalli & Mandya \\
\hline I & Costs & & & \\
& TVC & 20,658 & 20,265 & 20,412 \\
& & $(80.23)$ & $(80.23)$ & $(80.47)$ \\
& TFC & 4,887 & 4,993 & 4,953 \\
& & $(19.13)$ & $(19.77)$ & $(19.52)$ \\
& TC & 25,544 & 25,257 & 25,365 \\
& & $(100)$ & $(100)$ & $(100)$ \\
II & Returns & & & \\
& TR & 28,381 & 28,667 & 28,524 \\
& NR & 2,837 & 3,409 & 3,159 \\
& B:C Ratio & 1.11 & 1.13 & 1.12 \\
\hline
\end{tabular}

Note: TVC, TFC, TC, TR, NR and BC ratio denote Total Variable Cost, Total Fixed Cost, Total Cost, Total Returns, Net Returns and Benefit Cost ratio, respectively.

Figures in the parentheses indicate percentage to the total cost.

The results presented in the Table 6 showed that the cost of cultivation of ragi was found to be high in Srirangapatna taluk due to high variable and fixed costs. High variable cost was again because of high wage rate owing to non-availability of labour and high fixed cost was due to high rental value of owned land. The higher gross return from ragi was attributable to the higher prices of both main product and byproduct of ragi. But the total cost was comparatively low in case of Malavalli taluk. Gross and net returns were high in Malavalli taluk compared to Srirangapatna taluk. The result were in line with the findings of Harish (2006) and Narayanamoorthy (2013).

\section{Resource Use Efficiency: The Cobb-Douglas Model}

The resource use efficiency in the production of three main crops in the study area, namely, paddy, sugarcane and ragi was assessed using the Cobb-Douglas Production Function, wherein the regression coefficients also indicate the elasticities of production (Table 7). The analysis was done at farm level. The dependent variable was the gross returns (₹/farm) and the explanatory variables were farm size (ha), seeds (₹/ha), fertilizers (₹/ha), human labour (₹/farm), bullock labour (₹/farm), machine labour (₹/farm) and irrigation charges (₹/farm). The results of the regression analysis are presented in Table 7.

Table 7: Estimates of Cobb-Douglas Production Function

\begin{tabular}{|c|c|c|c|c|c|}
\hline $\begin{array}{l}\text { S1. } \\
\text { No. }\end{array}$ & Particulars & $\begin{array}{c}\text { Param- } \\
\text { eters }\end{array}$ & Paddy & $\begin{array}{l}\text { Sugar- } \\
\text { cane }\end{array}$ & Ragi \\
\hline 1 & Intercept & a & 2.10611 & 24.8658 & 4.1338 \\
\hline 2 & Farm Size (ha) & $X_{1}$ & -0.0025 & 1.9439 & 0.0000 \\
\hline 3 & Seeds (₹/farm) & $X_{2}$ & -0.1270 & -0.1861 & $-0.0901^{*+4}$ \\
\hline 4 & Fertilizer (₹/farm) & $x_{3}$ & $0.4170^{* *}$ & -1.9360 & $0.2062^{* * * *}$ \\
\hline 5 & $\begin{array}{l}\text { Human labour (₹/ } \\
\text { farm) }\end{array}$ & $X_{4}$ & $0.4498^{* * *}$ & 0.0050 & $0.1328^{* * *+}$ \\
\hline 6 & $\begin{array}{l}\text { Bullock labour (₹/ } \\
\text { farm) }\end{array}$ & $X_{5}$ & $0.2272^{* * *}$ & $0.7544^{* * *}$ & $0.1334^{* * *}$ \\
\hline 7 & $\begin{array}{l}\text { Machine labour } \\
\qquad(₹ / \text { farm })\end{array}$ & $X_{6}$ & 0.0481 & 0.3504 & 0.0000 \\
\hline \multirow[t]{4}{*}{8} & $\begin{array}{l}\text { Irrigation charge } \\
\text { (₹/farm) }\end{array}$ & $X_{7}$ & 0.0000 & 0.0000 & 0.6151 \\
\hline & $\mathrm{R}^{2}$ Value & & 0.9572 & 0.8613 & 0.9481 \\
\hline & F ratio & & $383.78^{* * *}$ & $47.62^{* * * *}$ & $179.27^{* * *}$ \\
\hline & Returns to scale & & 1.01 & 0.93 & 0.99 \\
\hline
\end{tabular}

Note: ${ }^{* * *},{ }^{* *}$ indicate significance at $1 \%$ and $5 \%$ levels, respectively.

\section{Paddy}

In paddy production, fertilizer, human labour and bullock labour had positive influence on the gross returns. While fertilizer was significant at 5 per cent level of probability, human labour and bullock labour were significant at 1 per cent level. Farm size and seeds were found to be negative and nonsignificant, whereas machine labour was positive and non significant. The $\mathrm{R}^{2}$ value was as high as 0.9572 thereby indicating a "Good Fit" of the model to the data. In other words, nearly 95.72 per cent of the variation in the gross returns from paddy was explained by all the seven explanatory variables included in the model. The returns to scale was almost equal to unity indicating constant returns to scale, thus implying that the use of all the resources put together was at lower level than the optimum usage level. The result were in line with the findings of Suresh and Keshav (2006).

\section{Sugarcane}

In the case of sugarcane, amongst all the variables included in the model, only bullock labour was found to be positive and significant at 1 per cent probability level. The remaining variables were 
non-significant. Nevertheless, the $\mathrm{R}^{2}$ value was 0.8613 indicating that 86.13 per cent of the variation in gross returns in sugarcane was explained by all the explanatory variables included in the model. The production function also indicated decreasing returns to scale ( $\mathrm{Sbi}=0.93$ ).

\section{Ragi}

In ragi production, four variables were found significant at 1 per cent probability level, namely, seeds, fertilizers, human labour and bullock labour. While fertilizers, human labour and bullock labour were positively significant, seed was negatively significant. The remaining three variables were found to be non-significant. Again, the $\mathrm{R}^{2}$ value was as high as 0.9481 , indicating that 94.81 per cent of the variation in gross returns in ragi was explained by all the explanatory variables included in the model. The production function also indicated decreasing returns to scale $(\mathrm{Sbi}=0.99)$ or a nearconstant returns to scale.

\section{Problems Faced by Farmers of Cauvery Basin in Farming}

The responses of the sample respondents on production related problems were converted into Garrett scores and are presented in the Table 8. The labour scarcity was the major problem expressed by the sample respondents faced by them in the production process. The Mean Garrett Score for this problem was 63.63 and hence the problem got assigned the first rank, followed by high wage rate (Mean Garrett Score=55.75), high cost of fertilizers (Mean Garrett Score=26.13), non-availability of seeds in time (Mean Garrett Score=22.22), nonavailability of fertilizers in time (Mean Garrett Score=21.22), heavy infestation of weeds (Mean Garrett Score=15.44), problem of pests and diseases (Mean Garrett Score=12.86), lack of storage facility at farm/village level (Mean Garrett Score=6.13) and non-availability of quality seeds (Mean Garrett Score=2.98).

The major problem observed in production was that of labour scarcity (Table 8). Apathy of youth towards agriculture and migration to urban areas has elevated the problem to further heights. The next major problem was that of high wages fuelled by scarcity of labour, particularly in peak seasons, viz., harvesting time especially for sugarcane crop.
Farmers also expressed concern regarding sky rocketing prices of inputs, particularly that of agrochemicals. Lack of timely availability of seeds and fertiliser was also a serious problem in the locality.

Table 8: Problems faced by farmers in the study area

\begin{tabular}{|c|c|c|c|}
\hline $\begin{array}{l}\text { Sl. } \\
\text { No. }\end{array}$ & Problems & Garrett Score & Rank \\
\hline A & Production related & & \\
\hline 1 & Labour scarcity & 63.63 & I \\
\hline 2 & High wage rate & 55.75 & II \\
\hline 3 & High cost of fertilizers & 26.13 & III \\
\hline 4 & Non-availability of seeds in time & 22.22 & IV \\
\hline 5 & $\begin{array}{c}\text { Non-availability of fertilizers in } \\
\text { time }\end{array}$ & 21.22 & $\mathrm{~V}$ \\
\hline 6 & Heavy infestation of weeds & 15.44 & VI \\
\hline 7 & Problem of pests and diseases & 12.86 & VII \\
\hline 8 & $\begin{array}{c}\text { Lack of storage facility at farm/ } \\
\text { village level }\end{array}$ & 6.13 & VIII \\
\hline 9 & Non-availability of quality seeds & 2.98 & IX \\
\hline B & Irrigation related & & \\
\hline 1 & $\begin{array}{l}\text { Untimely and inadequate } \\
\text { release of water from the dam }\end{array}$ & 36.43 & I \\
\hline 2 & Sedimentation problem & 36.36 & II \\
\hline 3 & $\begin{array}{l}\text { Wastage of water due to poor } \\
\text { maintenance of field channels }\end{array}$ & 25.99 & III \\
\hline 4 & $\begin{array}{c}\text { Non-availability of adequate } \\
\text { water due to poor management } \\
\text { of water }\end{array}$ & 15.28 & IV \\
\hline
\end{tabular}

The irrigation related problems faced by the sample respondents are also presented in the Table 8 . Untimely and inadequate release of water from the dam for irrigation purposes was the most serious problem faced by the farmers in the study area (Mean Garrett Score=36.43), followed by sedimentation problem (Mean Garrett Score=36.36). Due to sedimentation in canals and even field channels, the volume of flow of water to fields got reduced. This calls for immediate attention of the irrigation authorities to strengthen efforts towards proper maintenance of water canals, wastage of water due to poor maintenance of field channels (Mean Garrett Score=25.99) and non-availability of adequate water due to poor management of water (Mean Garrett Score=15.28). Negative externality of improper water management by the neighbouring farmers resulted in wastage of water in addition to adverse effects on soil health such as soil salinity and alkalinity. Indiscriminate usage of water by 
the farmers also meant less water availability to tail end farmers as and when they required. The results of the study were very similar to those reported by Mohan (2005), who identified untimely and inadequate supply of water as the major problem in canal sources of irrigation, while it was electricity failures/cuts and low output in the case of borewell sources.

\section{CONCLUSION}

The average age of the sample respondents was 45 years and nearly 90 per cent of them was literates (of which about 52 per cent completed high school education). Still, nearly 70 per cent of the households depend only on agriculture for their livelihood and the remaining on petty business in addition to agriculture. The average size of land holding in the study area was 2.71 acres, of which 2.54 acres area was under irrigation and the remaining 0.17 acre was cultivated under rainfed condition. Amongst crops, the yields of main product were the highest for sugarcane, followed by paddy and ragi. The differences in byproduct yields in the case of paddy and ragi were not significant. Srirangapatna taluka scored over Malavalli taluka in terms of yields of main products of all the crops under study, namely, paddy, sugarcane and ragi. The utilization of bullock and machine labour was the highest in sugarcane crop, followed by paddy and ragi. Between taluks, again it was Srirangapatna that scored over Malavalli in all the three selected crops, with the lone exception of bullock labour usage in sugarcane.

Flood irrigation method was adopted for almost all the crops which were grown in the district. The availability of canal water was continuous in kharif season and in summer it was available once in 10 days in Srirangapatna taluk and once in a month in Malavalli taluk. The adequacy of water was relatively good in Srirangapatna taluk than in Malvalli taluk. In general, Srirangapatna taluk had higher irrigated area for sugarcane and paddy compared to Malavalli taluk, whereas in ragi, it was the other way round. The labour scarcity, high wage rate and high cost of fertilizers were the top three problems faced by the sample respondents in crop production. Amongst the irrigation related problems, untimely and inadequate release of water from the dam for irrigation purposes, sedimentation problem and wastage of water due to poor maintenance of field channels were the most serious ones. These problems need to be addressed by the policy makers on priority basis.

\section{REFERENCES:}

Bohle, H. 2004. Vom Wasserkonflikt zur Wasserkrise - Der Niedergang eines südindischen Deltas. Geographische Rundschau, 56(12): 40-45.

Harish, M.H. 2006. An economic appraisal of land use dynamics in Mandya district. M.Sc. (Agri.) Thesis, Univ. Agric. Sci., Dharwad (India).

Mohan, L. 2005. Economic efficiency of cropping pattern under different sources of irrigation. M.Sc. (Agri.) Thesis, Univ. Agric. Sci., Dharwad (India).

Narayanamoorthy, A. 2013. Profitability in crops cultivation in India: some evidence from cost of cultivation survey data. Indian J. Agri. Econ., 68(1): 104-120.

Narendra, P.N. 2009. Institution that cannot manage change: A Gandhian perspective on the Cauvery dispute in South India, Water Alternatives, 2(3): 315-327.

Ningareddy, P. 2005. A study on knowledge, extent of participation and benefits derived by participant farmers of the watershed development programme. M.Sc. (Agri.) Thesis, Univ. Agric. Sci., Dharwad (India).

Pavankumar, B.G. 2011. Economics of Bt. Cotton cultivation - a comparative analysis across different farm sizes in northern transitional zone, Karnataka. M.Sc. (Agri) Thesis, Univ. Agric. Sci., Dharwad (India).

Pradeep, 2006. An economic analysis of woolly aphid infestation on sugarcane in Mandya district of Karnataka. M.Sc. (Agri.) Thesis, Univ. Agric. Sci., Dharwad (India).

Prasad, R. 2007. National dialogue to review and evolve parameters for interstate transboundary water sharing in India. National Institute of Advanced Studies (NIAS), pp. 2-5.

Puhazendi, V. 2000. Evaluation study of Self-Help Groups in Tamil Nadu. NABARD, Mumbai, pp. 54-59.

Suresh, A. and Keshav Reddy, T.R. 2006. Resource use efficiency of paddy cultivation in peechi command area of Thrissur district of Kerala: An economic analysis. Agric. Econ. Res. Rev., 19(1-6): 159-171. 
